Tropical Journal of Pharmaceutical Research September 2019; 18 (9): 1889-1893

ISSN: 1596-5996 (print); 1596-9827 (electronic)

(1) Pharmacotherapy Group, Faculty of Pharmacy, University of Benin, Benin City, 300001 Nigeria.

\title{
Immunosuppressive effect of voacamine from Voacanga africana Stapf based on SPRi experiment
}

\author{
Hong Xiang $\mathrm{Li}^{1,2}$, Yan Qiu Wang ${ }^{3}$, Jin Shuang Zhao ${ }^{3}$, Li Xia Zhu ${ }^{2}$, Wen Ying \\ Huai $^{3}$, Rong Qiang Liu ${ }^{3}$, Tian E Zhang ${ }^{3 *}$, Yun Deng ${ }^{2}$ \\ ${ }^{1}$ Institute of Innovation, ${ }^{2}$ The Ministry of Education Key Laboratory of Standardization of Chinese Herbal Medicine, ${ }^{3}$ College of \\ Basic Medical Sciences, Chengdu University of Traditional Chinese Medicine, Chengdu 611137, PR China
}

*For correspondence: Email: zhte2003@aliyun.com, dengyun2000@hotmail.com

\begin{abstract}
Purpose: To investigate the affinity of a bis-indole alkaloid - voacamine from Voacanga Africana Stapf for IL-2Ra - and its immunosuppressive effect on concanavalin A-induced $T$ cell proliferation and lipopolysaccharide -induced $B$ cell proliferation in vitro.

Methods: Surface plasmon resonance imaging (SPRi) was used to screen the target protein of voacamine, while CCK-8 kit was used to evaluate cytotoxicity. Mitogen-induced proliferation assay was carried out to assess the inhibitory effect of voacamine on Con A-induced T cell proliferation and LPSinduced $B$ cell proliferation. The binding characteristics of voacamine were investigated using a binding model with IL-2Ra constructed based on molecular docking simulation.

Results: Voacamine had a high-affinity for IL-2Ra with an equilibrium dissociation constant $\left(K_{D}\right)$ of $1.85 \times 10^{-8} \mathrm{M}$. Cytotoxicity data showed that voacamine did not exhibit cytotoxicity at concentrations lower than $0.32 \mu \mathrm{M}$. However, it exerted significant immunosuppressive effect on $B$ cells at a lower concentration, but had no influence on proliferation of $T$ cells. Autodock results indicate that voacamine has a good interaction with the enzyme active site.

Conclusion: Voacamine and its analogues exert influence on the immune system.
\end{abstract}

Keywords: Immunosuppressive, IL-2Ra, SPRi, Voacanga africana Stapf Voacamine

This is an Open Access article that uses a fund-ing model which does not charge readers or their institutions for access and distributed under the terms of the Creative Commons Attribution License (http://creativecommons.org/licenses/by/4.0) and the Budapest Open Access Initiative (http://www.budapestopenaccessinitiative.org/read), which permit unrestricted use, distribution, and reproduction in any medium, provided the original work is properly credited.

Tropical Journal of Pharmaceutical Research is indexed by Science Citation Index (SciSearch), Scopus, International Pharmaceutical Abstract, Chemical Abstracts, Embase, Index Copernicus, EBSCO, African Index Medicus, JournalSeek, Journal Citation Reports/Science Edition, Directory of Open Access Journals (DOAJ), African Journal Online, Bioline International, Open-J-Gate and Pharmacy Abstracts

\section{INTRODUCTION}

Interleukin-2 (IL-2) is a member of a cytokine family involved in the immune system. It mediates its effects by binding to three different cell surface receptors: IL-2Ra chain, IL-2R $\beta$ chain and IL-2Ry chain [1]. The receptor IL-2 $\alpha$ is expressed by $T$ cells after activation of $T$ cell receptors. The interaction of IL-2 with its receptors leads to proliferation of $T$ cell, $B$ cell, and natural killer (NK) cell, and clonal expansion [2].

Voacanga africana Stapf ex Scott-Elliot is a small tropical tree found mainly in West Africa [3]. The crude extract of its stem bark exerts a variety of pharmacological effects, and it has been used for the treatment of leprosy, diarrhea, generalized oedema, convulsions in children, and mental problems [3-5]. Previous studies showed that 
alkaloids from this plant are bioactive compounds $[6,7]$. Voacamine (Figure 1) is one of the major alkaloids with strong antitumor effects [8]. It is also used with chloroquine and artemisinin for malaria treatment in vivo [9].

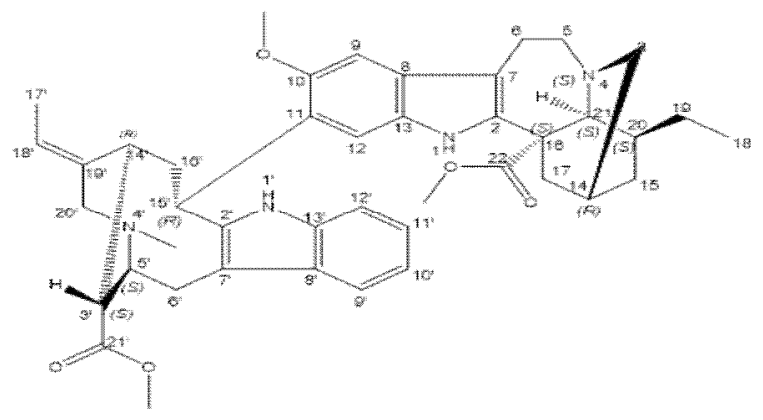

Figure 1: Structure of voacamine

\section{EXPERIMENTAL}

\section{Plant material}

The bark of $V$. africana Staph. was purchased from Ghana, Africa in April 2012 and was identified by Dr Hai-Feng Liu, Sichuan University. A voucher specimen (no. FKS-20120421-JN) was deposited in the herbarium of Laboratory of Chinese Medicinal Chemistry, Pharmaceutical College, Chengdu University of Traditional Chinese Medicine.

\section{Measurement of SPRi}

The measurement of SPRi was carried out in line with the procedure described previously [10]. Proteins were diluted to a final concentration of $0.5 \mathrm{mg} / \mathrm{mL}$ with PBS and applied onto bare goldcoated (thickness $47 \mathrm{~nm}$ ) PlexArray Nanocapture Sensor Chip (Plexera Bioscience, seattle, WA, USA) at $40 \%$ humidity, using PDMS. The surface of the chips was first activated with sulfoNHS/EDC (0.1 and 0.4 M, in Milli-Q water). The chip was blocked with $1 \mathrm{M}$ ethanolamine $(\mathrm{pH} 8.5)$ for $30 \mathrm{~min}$. All measurements were performed at the wavelength of $660 \mathrm{~nm}$. Then, the sample (20 $\mu \mathrm{M})$ and positive control (rapamycin; $10 \mu \mathrm{M}$ ) were injected into the $30 \mu \mathrm{L}$ flow cell at a flow rate of $1 \mu \mathrm{L} \mathrm{sec}{ }^{-1}$ using a non-pulsatile piston pump. The surface was washed with PBS at $1 \mu \mathrm{L}$ $\mathrm{sec}^{-1}$, and regenerated with $0.5 \%(\mathrm{v} / \mathrm{v}) \mathrm{H}_{3} \mathrm{PO}_{4}$ at $1 \mu \mathrm{L} \mathrm{sec}{ }^{-1}$ for $300 \mathrm{sec}$. All measurements were performed at $4{ }^{\circ} \mathrm{C}$. The signal changes after binding and washing were recorded, and selected protein-grafted regions in the SPRi were analysed. Real-time binding signals were recorded and analysed with Data Analysis Module (DAM, Plexera Bioscience, Seattle, WA, USA).

\section{Assay of biological activity}

The biological activity was assayed as described in a previous study $[11,12]$.

\section{Reagents}

Concanavalin A (Con A), lipopolysaccharide (LPS, Escherichia coli 055: B5), CCK-8; WST-8 [2-(2-methoxy-4-nitrophenyl)-3-(4nitrophenyl)-5(2, 4-disulfophenyl)-2H-tetrazolium, monosodium salt], and RPMI 1640 medium were purchased from GibcoBRL, Life Technologies (USA). Fetal bovine serum (FBS) was product of HyClone Laboratories (Utah, USA). $\left.{ }^{3} \mathrm{H}\right]$-Thymidine (10 $\mu \mathrm{Ci} / \mathrm{mL})$ was obtained from the Shanghai Institute of Atomic Energy (SIAE).

\section{Experimental animals}

BALB/c mice were purchased from Shanghai Experimental Animal Center and were housed in a controlled environment (12-h light/12-h dark photoperiod at a temperature of $22 \pm 1^{\circ} \mathrm{C}$ and relative humidity of $55 \pm 5 \%$. All animal experiments were carried out according to the $\mathrm{NIH}$ Guide for Care and Use of Laboratory Animals [13] and were approved by the Bioethics Committee of the Shanghai Institute of Materia Medica (nos. SCXK 2002-0010; SCXK 20030029).

\section{Preparation of spleen cell suspensions}

Mice were sacrificed by cervical dislocation, and mononuclear cell suspensions of spleens were prepared after the removal of cell debris and clumps. The erythrocytes were lysed with Trisbuffered ammonium chloride. Lymphocytes were washed and re-suspended in RPMI 1640 medium containing $10 \%$ fetal bovine serum, penicillin (100 U/mL), and streptomycin (100 $\mathrm{mg} / \mathrm{mL})$.

\section{Cytotoxicity assay}

The mice spleen cells were seeded into 96-well plates at a density of $1 \times 10^{-6}$ cells per well in the presence or absence of various concentrations of voacamine solution, and incubated in humidified incubator at $37^{\circ} \mathrm{C}$ and $5 \% \mathrm{CO}_{2}$ for $48 \mathrm{~h}$. Then, a certain amount of CCK-8 was added to every well after 8 - $10 \mathrm{~h}$ of culture, and absorbance was read at a wavelength of $450 \mathrm{~nm}$ in a microplate reader (Bio-Rad 650).

\section{Mitogen-induced proliferation assay}

Mice spleen cells were seeded into 96-well plates at a density of $5 \times 10^{5}$ cells per well, and 5 
$\mu \mathrm{g} / \mathrm{mL}$ of Con A or $10 \mu \mathrm{g} / \mathrm{mL}$ of LPS, and various concentrations of samples were added simultaneously in order to induce $\mathrm{T}$ cell or B cell proliferative responses. The mixtures were incubated at $37{ }^{\circ} \mathrm{C}$ and $5 \% \mathrm{CO}_{2}$ for $48 \mathrm{~h}$. Proliferation was assessed in terms of uptake of $\left[{ }^{3} \mathrm{H}\right]$-thymidine within $8 \mathrm{~h}$ after addition of $25 \mu \mathrm{L}$ $\left[{ }^{3} \mathrm{H}\right]$-thymidine. Then, the cells were harvested onto glass fiber filters, and the incorporated radioactivity was counted using a Beta Scintillation Counter (MicroBeta Trilux, PerkinEIMER Life Sciences). Lymphocyte proliferation was calculated in terms of $\pm \%$ by subtracting the CPM value of positive control. In the absence of cytotoxicity, proliferation value of more than $\pm 15 \%$ indicated that the sample had a strong enhancement/inhibitory effect on lymphocytes.

\section{Molecular docking simulation}

The crystal structure of IL-2Ra derived from Protein Data Bank [14] was used as a target for molecular docking simulation, and the 3D structure of voacamine was generated using Chembio3D Utra 14.0, followed by energy minimization molecular docking simulation performed with Autodock 4.0 software. The Autodock program operates with pre-generated grid maps in a way that conformational flexibility of the IL-2Ra is not considered during the docking process. Ligand and water molecules in crystal structure were removed. The affinity grids were centered on the pre-defined active site of protein with dimensions of $50 \times 60 \times 50 \AA$. As a docking algorithm, a Lamarckian genetic algorithm (LGA) [15-17] was adopted in the molecular docking simulation, and the number of individuals for the population was set as 100 . The docking models were analyzed and represented using ADT and Pymol.

\section{RESULTS}

Based on SPRi test, data for each imprint spot was obtained. These data showed that IL-2Ra had a much higher binding signals than that of bovine serum albumin (BSA). Voacamine was able to bind to IL-2Ra with an equilibrium dissociation constant $\left(K_{D}\right)$ of $1.85 \times 10^{-8} \mathrm{M}$, as shown in Figure 2.

Due to the fact that IL-2Ra is involved in lymphocyte cell proliferation, the immunesuppressive effect of voacamine was investigated using a previously reported method [18], with cyclosporine A (CsA) as the positive control. The pharmacological results are summarized in Table 1. Voacamine did not exhibit cytotoxicity at a lower concentration $(0.32$ $\mu \mathrm{M}$ ), but when this concentration was exceeded, it exhibited cytotoxic effect against lymphocytes, and even killed lymphocytes completely. Within non-noxious concentration range, voacamine exhibited significant inhibitory bioactivity against LPS-induced B lymphocyte cell proliferation. However, it had no significant inhibitory effect on Con A-induced T lymphocyte cell proliferation, and there was no dose-dependent relationship.
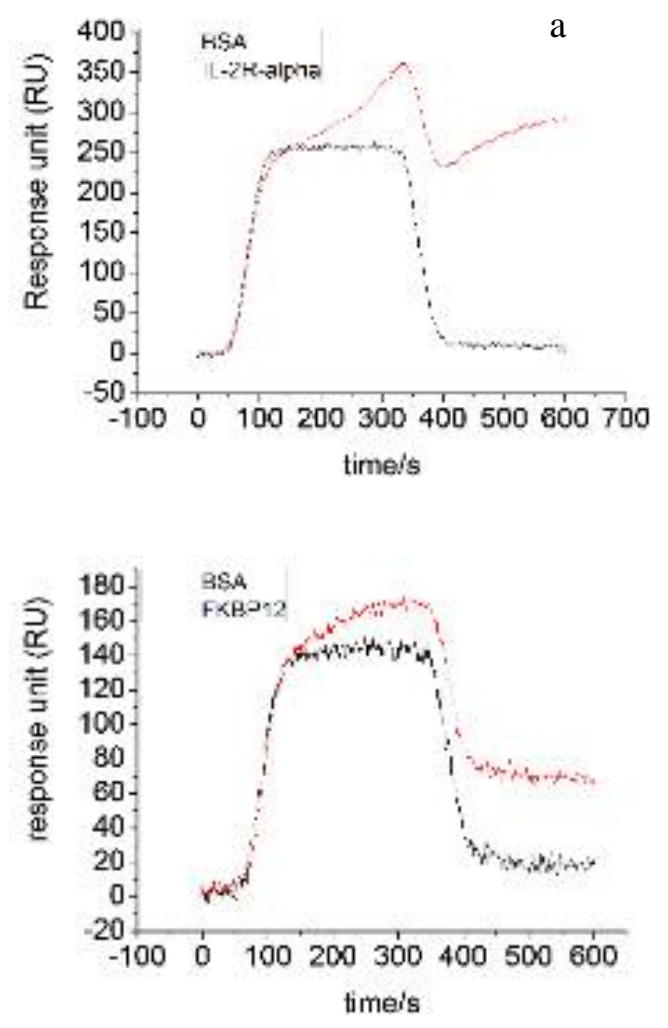

Figure 2: a: Binding signal from IL-2Ra to voacamine. b: The binding signal from FKBP12 to rapamycin (rapamycin and FKBP12 used as positive control); $K_{D}$ $=2 \times 10^{-8} \mathrm{M}$

For the analysis of complexed structures of voacamine with IL-2Ra obtained by molecular docking simulation, the best docking mode was determined by choosing the poses with the lowest energy for voacamine, as shown in Figure 3 . Results revealed that voacamine was bound to the active site of IL-2Ra protein at the surface through Met25, Asn37, Cys28, Glu29, Cys30, Arg36, Leu42, Tyr43 and His120 residues. The binding between voacamine and IL-2Ra protein involved Van der Waals interactions, hydrophobic interactions and hydrogen bonds. The ketone group at C-21' played an important role and formed $\mathrm{H}$-bonds with Arg36 (1.8 A). 
Table 1: Effect of voacamine on murine lymphocyte proliferation induced by Concanavalin A (ConA) $(5 \mu \mathrm{g} / \mathrm{mL})$ or lipopolysaccharide (LPS)

\begin{tabular}{lcccc}
\hline Compound & $\begin{array}{c}\text { Concentration } \\
(\boldsymbol{\mu M})\end{array}$ & Cytotoxicity & \multicolumn{2}{c}{ Inhibition (\%) } \\
\cline { 3 - 5 } & & & $\begin{array}{c}\text { CoA-induced T } \\
\text { cell proliferation }\end{array}$ & $\begin{array}{c}\text { LPS-induced B cell } \\
\text { proliferation }\end{array}$ \\
\hline Voacamine & 20.000 & + & -100 & -100 \\
& 4.000 & + & -100 & -100 \\
& 0.800 & + & -5 & -27 \\
& 0.160 & - & 6 & -26 \\
& 0.032 & - & -3 & -22 \\
\hline
\end{tabular}

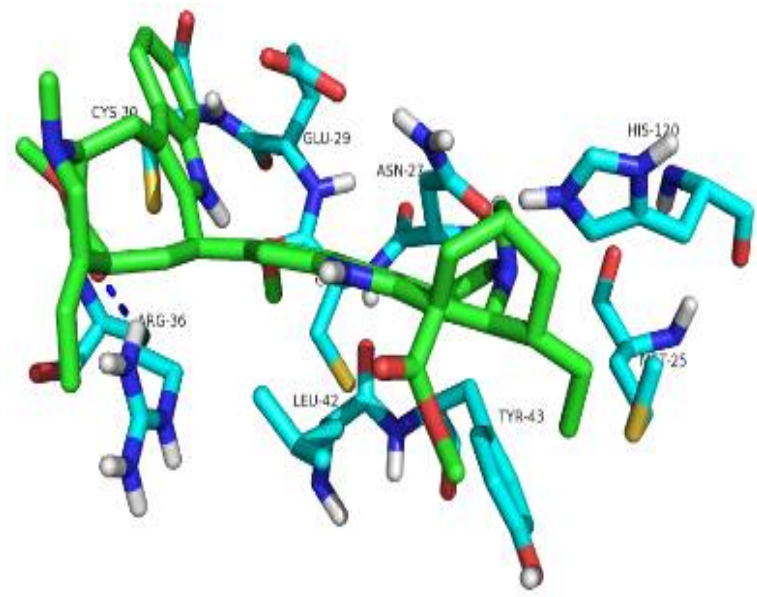

Figure 3: The binding mode of voacamine to IL-2Ra as predicted with molecular docking simulation. The dashed line denotes $\mathrm{H}$-bond

\section{DISCUSSION}

Surface plasmon resonance imaging (SPRi) is a real-time, label-free, and high-throughput sensor technique widely used to study biomolecular interactions based on detection of changes in refractive index due to molecular binding. In this study, this high-throughput method was used for simultaneous monitoring of interactions between voacamine and different proteins. The results revealed that voacamine binds to IL-2Ra. This implies that the biological effect of voacamine may affect the immune system. Typically, a protein that binds to a drug not indicated exist biological activity, because SPRi experiment is not able to predict binding sites of the protein. The immunosuppressive effect of voacamine on lymphocyte cell proliferation was evaluated. Moreover, molecular docking simulation was used for analysis of complexed structures of voacamine with IL-2Ra. The autodock results indicated that voacamine had a good interaction with the enzyme active site. The molecular docking simulation and SPRi experiment indicate that voacamine has binding interaction with IL$2 \mathrm{Ra}$. These results also suggest that voacamine may exert an influence on the immune system when developed into a drug.

\section{CONCLUSION}

The findings of this study show that voacamine has a high affinity for IL-2Ra, indicating that the bioactivity of voacamine is probably relevant to the immune system. At certain concentrations, voacamine exhibits in vitro cytotoxic effects on lymphocytes. Within non-noxious concentration range, it suppresses LPS-induced B lymphocyte cell proliferation, but has no inhibitory effect on Con A-induced $\mathrm{T}$ cell proliferation. Molecular docking analysis has provided insight into the mode of interaction of voacamine with IL-2R receptor.

\section{DECLARATIONS}

\section{Acknowledgement}

We thank Professor Jian-Ping Zuo at Shanghai Institute of Materia Medica, Chinese Academy of Sciences for Biological Activity Evaluation. This work was supported by the Youth Science and Technology Innovative Research team fund project of Sichuan (grant no. 2016TD0006); the Key Fund Project for Education Department of Sichuan (grant no. 17ZA161); Science and Technology Development Fund of Chengdu University of TCM (grant no. ZRQN1563), and the Training Project of Academic and Technology Leader of Sichuan.

\section{Conflict of interest}

No conflict of interest is associated with this work

\section{Contribution of authors}

The authors declare that this work was done by the authors named in this article and all liabilities pertaining to claims relating to the content of this article will be borne by them. Hong Xiang Li and Yan Qiu Wang contributed equally.

\section{Open Access}

This is an Open Access article that uses a funding model which does not charge readers or their 
institutions for access and distributed under the terms of the Creative Commons Attribution License (http://creativecommons.org/licenses/by/ 4.0) and the Budapest Open Access Initiative (http://www.budapestopenaccessinitiative.org/rea d), which permit unrestricted use, distribution, and reproduction in any medium, provided the original work is properly credited.

\section{REFERENCES}

1. Mao Z, Fu XG, Dong ZY, Jian XD, Sun J, Wei J. Study of the molecular mechanism of interleukin-2 mutein $D 10$ binding to IL-2 receptors by molecular simulations. $\mathrm{Mol}$ Simulat, 2018; 44: 973-980.

2. Rickert $M$, Wang $X Q$, Boulanger $M J$, Goriatcheva $N$, Garcia KC. The Structure of Interleukin-2 Complexed with its Alpha Receptor. Science, 2005; 308: 1477-1480

3. Iwu MM. Handbook of African Medicinal Plants. Florida: CRC Press Inc, 1993; 257.

4. Neuwinger HD. African traditional medicine: a dictionary of plant use and applications. Stuttgar: Medpharm Scientific Publishers, 2000.

5. Tan PV, Penlap VB, Nyasse B, Nguemo JD. Anti-ulcer actions of the bark methanol extract of Voacanga africana in different experimental ulcer models in rats. $J$ Ethnopharmacol, 2000; 73: 423-428.

6. Diavara D, Pyuskyulev B, Kuzmanov B. Alkaloid-bearing plants in the flora of Guinea. Alkaloids from Voacanga africana Stapf. Izvestiya po Khimiya, 1984; 17: 364-371.

7. Stoeckigt J, Pawelka KH, Karl H, Tanahashi T, Danieli $B H$, William E. Voafrine $A$ and Voafrine $B$, New Dimeric Indole Alkaloids from Cell Suspension Cultures of Voacanga africana Stapf. Helv Chim Acta, 1983; 66 : 2525-2533.

8. Chen HM, Yang YT, Li HX, Cao ZX, Dan XM, Mei L, Guo $D L$, Song CX, Dai Y, Hu J, Deng Y. Cytotoxic monoterpenoid indole alkaloids isolated from the barks of Voacanga Africana Staph. Nat Prod Res, 2015; 30: 1 6.

9. Condello M, Cosentino D, Corinti S, Felice GD, Multari $G$, Gallo FR, Arancia G, Meschini S. Voacamine Modulates the Sensitivity to Doxorubicin of Resistant Osteosarcoma and Melanoma Cells and Does Not Induce Toxicity in Normal Fibroblasts, J Nat Prod, 2014; 77: 855-862.

10. Wang YQ, Li HX, Liu XC, Zhao JS, Liu RQ, Huai WY, Zhang TE, Deng Y. One bis-indole alkaloid-voacamine from Voacanga africana Stapf: biological activity evaluation of PTP1B in vitro utilizing enzymology method based on SPRi experiment. Nat Pro Res, 2018; doi: 10.1080/14786419.2018.1480623.

11. Fan YY, Gan LS, Liu HC, Li H, Xu CX, Zuo JP, Ding J, Yue JM. Phainanolide A, Highly Modified and Oxygenated Triterpenoid from Phyllanthus hainanensis. Org Lett, 2017; 19: 4580-4583.

12. Chen HL, Du XL, Tang W, Zhou Y, Zuo JP, Feng HJ, Li $Y C$. Synthesis and structure-immunosuppressive activity relationships of bakuchiol and its derivatives. Bioorgan Med Chem, 2008; 16: 2403-2411.

13. Anonymous. NIH requests information on care of laboratory animals. Am J Vet Res, 2006; 67: 204-205.

14. Rickert M, Wang X, Boulanger MJ, Goriatcheva N, Garcia $K C$. The structure of interleukin-2 complexed with its alpha reptor. Science, 2005; 308: 1477-1480.

15. Morris GM, Goodsell DS, Halliday RS, Huey R, Hart WE, Belew RK, Olson AJ. Automated docking using a Lamarckian genetic algorithm and an empirical binding free energy function. J Comput Chem, 1998; 19: 16391662.

16. Mesaik MA, Murad S, Ismail Z, Abdullah NR, Gill HK, Yousaf $M$, Siddiqui RA, Ahmad A, Choudhary MI. Biological and molecular docking studies on coagulin- $\mathrm{H}$ : Human IL-2 novel natural inhibitor., Mol Immunol, 2006; 43: 1855-1863.

17. Chen $L, L i H L$, Liu J, Zhang $L Y$, Liu $H$, Jiang $H L$. Discovering benzamide derivatives as glycogen phosphorylase inhibitors and their binding site at the enzyme, Bioorgan Med Chem, 2007; 15: 6763-6774.

18. Zhang S, Huang Y, He S, Chen H, Li Z, Wu B, Zuo J, Feng $T$, Liu J. Albatredines $A$ and $B$, a pair of epimers with unusual natural heterocyclic skeletons from edible mushroom Albatrellus confluens, RSC Adv, 2018; 8: 23914-23918. 